\title{
The Impact of the Number of Athletes and Coaches on Sporting Success with the Budget Contribution
}

\author{
Alparslan Gazi Aykın ${ }^{*}$, Eyyüp Sarıkol ${ }^{2}$ \\ University, Hatay, Turkey \\ Turkey \\ Study Area: Erzurum, Turkey \\ Coordinates: $41^{\circ} \mathrm{oo}^{\prime} 49$ ? $\mathrm{N} 28^{\circ} 57^{\prime} 18$ ? E
}

'School of Physical Education and Sports, Hatay Mustafa Kemal

${ }^{2}$ School of Physical Education and Sports, Iğdır University, Iğdır,

Key words: Budget contribution, Sporting success

Statement: This work; Presented in the virtual environment at the 3rd International Sports and Wellness Congress for All held between 10-14 June 2020.

\section{Introduction:}

In today's modern world where transmodern approaches take us to the future. The role of money in the development of any modern or post modern society emerges as an undeniable reality. This situation creates an environment in which the budget is handled in terms of economic and financial relations, and the success in achieving the goals in the economy is attributed to the accuracy of the budget estimates. In such an environment, the issue of whether the budget plays a role in the achievements that can be achieved in different issues outside the economy appears as one of the neglected or incomplete topics. As a result, the institutional functioning of the budget is a fact that

\section{Abstract}

It is seen that the studies on the budget in our country are mostly handled in the context of economic and financial relations. The studies on the relationship between sporting success and budget are almost nonexistent makes this study important. It is aimed to reveal the effect of annual increases in budgets allocated to the autonomous and independent sports federations from the General Directorate of Sports Services, based on the international medals earned, the number of athletes and the number of coaches. The data in this study were obtained from the General Directorate of Sports Services. The effect of the budget contribution provided to the federations on the number of international medals, athletes and coaches and the linear relationship between the variables was analyzed by using Regression and Correlation Analysis. It was seen that the correlation analysis between the budget allocated to the federations from the General Directorate of Sports Services and the number of athletic achievements, the number of licensed athletes, the number of active athletes and the number of coaches. While the relationship level was not significant, there was a significant relationship between the number of athletic achievement and the number of licensed athletes, the number of active athletes and the number of coaches. Besides, it has been determined that the number of licensed and active athletes and coaches affects sporting success, and the budget allocated to federations has no statistically effect on sporting success. Although financial possibilities are effective in corporate success, the specific nature of sports points to the effect of non-budgetary factors in sporting success.

institutional functioning can affect the effectiveness and success of the organization in the fields it operates. In this context, the study of the effect of the budget on sportive success makes this study important.

The first thing that comes to mind when it comes to sports success is the medals received in the field of sports. Especially if we think in terms of Turkey, he received a degree in international championships medal on behalf of Turkey, and the number is an indicator of what that be in terms of sporting achievement. However, how much is it that a country's success in the field of sports is attributed only to the degree and number of medals it is a controversial issue that it is a correct approach. Just as, students' school success should not be evaluated only according to the 
grades they received, and their psychological and social status should also be considered (Türkoglu, 2008); the same is true for the success of athletes. Although the success of a country or athlete in a sports organization is determined by the number of medals received, it would be a wrong approach to think that success is limited only to the number of medals, regardless of the social, cultural and economic status of the countries (Altun \& Koçak, 2015).

It is a fact that the success in the field of sports can also be viewed in terms of the place and prevalence of the sport in the society. It is a mistake to think that the societies where sports have become a lifestyle have failed even in sports, even if the number of medals is low. Because of its advanced as a lifestyle of sports in society today as it was in the world, Turkey's sports policy is known that the sport is set out as a priority goal of spreading to the community (Aykin \& Know, 2013). The budget is a factor in the studies for the promotion of sports. The increase in the number of athletes and coaches as the society turns towards sports as a result of taking the right steps indicates a society where sports is a lifestyle as an indicator that sports is becoming widespread. Considering the increase or decrease in the number of medals, sports success occurs. In this context; explaining the relationship between budget, number of athletes and coaches and sporting success will make the subject more understandable.

Budget and Sportive Success: Budget is defined as all of the income and expenses that the state, an organization, a family or someone designs for a certain period of time in the future (www.sozluk.gov.tr). Success is defined as the individual's reaching the target by making a planned, programmed effort with a voluntary desire in a motivated manner, believing that he can do it willingly, desiring (Basar, 2001). Based on this def inition, sportive success; knowingly and willingly, it can be expressed as achieving goals in the field of sports as a result of a planned and programmed effort.

One of the most important factors for sporting success at the international level is economic conditions (Jayantha \& Ubayachandra, 2015). With the increase in the budget of the General Directorate of Sports, the successes in the international organizations and competitions hosted are increasing (Erkan, 2014). However, it would not be correct to say that the increase in the budget always increases the sportive success. Because, although some federations have a lower budget, they can be more successful than many federations with a higher budget in terms of medals (Altun \& Koçak, 2015).

While reviewing the literature, it is possible to come across studies examining the relationship between financial performance and sportive success. While many of these studies emphasized that financial performance positively affects sportive success; In some studies, it is stated that there is no correlation between sportive success and financial performance and there is no statistically significant relationship between these two variables.

Güngör (2014), in the study that covers the 6-year period between 2007-2012 and examines the relationship between sports performance and financial performance in football; revealed that there is a parallel between sportive success and income from professional football activities.

Pereira (2018)'s study on 36 European Clubs between 2010-2017; examined the relationship between financial performance and sports performance in football clubs and reached the conclusion that more financially stable clubs were more successful in terms of sports.

Rohde \& Breuer (2016)'s research on European elite football; showed that financial success is driven by sporting success in the national and international arena. Barajas et al. (2005) found a nonlinear relationship between the budget of Spanish football clubs (expected income) and sports performance, with a rating of $55.12 \%$. Göllü (2012) studied the effects of financial performance of club companies on sportive performance in the period 2002-2009. It revealed that there was no correlation between the financial performances of club companies such as Trabzonspor, Fenerbahçe, Galatasaray and Besiktas and the sportive performances of the clubs.

Sakinc et al. (2017) examining the relationship between success in sports and financial performance in European Football; concluded that there was no statistically significant relationship between success and financial performance in sports. The increase in the sports budget, the number of athletes stated that the increase in the number of athletes would increase the number of medals, and that there was a statistical relationship between the sports budget and the number of athletes and the number of athletes increases when the sports budget increases, but the increase in the number of athletes does not affect the number of medals. In addition, in this study by Elmas (2016) It was revealed that there was no relationship between the budget and the number of medals.

Countries that invest more in economics are likely to be more successful in sports events (Bernard \& Busse, 2004). Saatçioglu (2013) reports that the country's level of development positively affects the number of medals earned.

According to the $4^{\text {th }}$ article of the Application and Accounting and Registration Procedures and Principles of the Independent Sports Federations Accounting and Budget Implementation Directive, General Directorate aids; It consists of the share to be allocated from the General Directorate budget for the related sports branch and the Project Grant to be transferred to support the projects to be prepared by the federations regarding the infrastructure and education. In the 31st article of the Accounting and Budget Implementation Directive of Independent Sports Federations, the contribution of these aids to the 
promotion of our country, whether the federations have an Olympic branch or not, the activity of the branch of sports in the previous years, the activities and activities they carried out, active clubs, athletes, trainers and criteria such as the number of referees, important national and international sports organizations in Turkey and abroad, sponsorship revenues and whether they will be able to provide sponsors for their projects, their sporting achievements, the expenses they plan to make in the next period, their own revenues and the results of inspection, investigation and investigation reports. It is stated that it is determined by taking.

As per Viseu (2000), the sports budget depends on different variables such as money, time, presentation type, institutions, sports motive, demography and participation in sports. The budgets provided to the federations are not considered sufficient to be successful in sports events (Altun \& Koçak, 2015). Istanbul Chamber of Certified Public Accountant and "Turkey's Fitness Budget: High Cost of Victory" according to the report titled; While the cost of a medal was 4.1 million Turkish Liras in the Olympics held in 1936, the cost of a medal obtained in the 2012 Olympics was 946 million Turkish Liras. In this report; According to federation budgets, it is stated that there are significant differences between the amount of money per active athlete. In addition, the report; 113 TL per year per licensed athlete, 489 TL per year per active athlete. reveals that it fell. All these data point to money in sports success, that is, the importance of budget support.

\section{Methodology:}

According to the 4th article of the Application and Accounting and Registration Procedures and Principles of the Independent Sports Federations Accounting and Budget Implementation Directive, General Directorate aids; It consists of the share to be allocated from the General Directorate budget for the related sports branch and the Project Grant to be transferred to support the projects to be prepared by the federations regarding the infrastructure and education. In the 31st article of the Accounting and Budget Implementation Directive of Independent Sports Federations, the contribution of these aids to the promotion of our country, whether the federations have an Olympic branch or not, the activity of the branch of sports in the previous years, the activities and activities they carried out, active clubs, athletes, trainers and criteria such as the number of referees, important national and international sports organizations in Turkey and abroad, sponsorship revenues and whether they will be able to provide sponsors for their projects, their sporting achievements, the expenses they plan to make in the next period, their own revenues and the results of inspection, investigation and investigation reports. It is stated that it is determined by taking.

As per Viseu (2000), the sports budget depends on different variablessuchas money, time, presentation type,institutions, sports motive, demography and participation in sports. The budgets provided to the federations are not considered suff icient to be successful in sports events (Altun \& Koçak, 2015). Istanbul Chamber of Certified Public Accountant and "Turkey's Fitness Budget: High Cost of Victory" according to the report titled; While the cost of a medal was 4.1 million Turkish Liras in the Olympics held in 1936, the cost of a medal obtained in the 2012 Olympics was 946 million Turkish Liras. In this report; According to federation budgets, it is stated that there are significant differences between the amount of money peractive athlete. In addition, the report; 113 TL per year per licensed athlete, 489 TL per year per active athlete. reveals that it fell. All these data point to money in sports success, that is, the importance of budget support.

In Table-1; According to years, scores obtained from World and European Championships and their average points can be seen. The average score of the World and European Championships for the period 2007-18 is 4474.35.

\begin{tabular}{|c|c|c|c|c|}
\hline YEARS & $\begin{array}{l}\text { SHGM Budget } \\
\text { Contribution }\end{array}$ & $\begin{array}{l}\text { Number of } \\
\text { Coaches } \\
\text { (TL) }\end{array}$ & $\begin{array}{l}\text { Number of } \\
\text { Licensed of } \\
\text { Athletes }\end{array}$ & $\begin{array}{l}\text { Number } \\
\text { Active } \\
\text { Athletes }\end{array}$ \\
\hline 2007 & 76.826 .000 & 75984 & 1262891 & 209436 \\
\hline 2008 & 75.082 .000 & 88482 & 1469352 & 255037 \\
\hline 2009 & 136.202 .000 & 102971 & 1621349 & 312668 \\
\hline 2010 & 137.778 .000 & 110705 & 1764756 & 267857 \\
\hline 2011 & 106.600.000 & 135738 & 1951216 & 287417 \\
\hline 2012 & 73.716.000 & 155917 & 2331159 & 429507 \\
\hline 2013 & 75.227 .000 & 171870 & 2817773 & 566056 \\
\hline 2014 & $102.137 \cdot 700$ & 192880 & 3219324 & 485330 \\
\hline 2015 & 119.000 .000 & 212045 & 3534312 & 451420 \\
\hline 2016 & $97 \cdot 752.000$ & 233070 & 3841600 & 468012 \\
\hline 2017 & 84.266 .524 & 251182 & 4428835 & 710059 \\
\hline 2018 & 94.700 .000 & 266379 & 4907955 & 695698 \\
\hline
\end{tabular}

This research is a descriptive and quantitative study that examines the relationship between the budget contribution made to the Federations from the General Directorate of Sports Services and the number of coaches and athletes in sports success.

The data obtained were analyzed in SPSS 21.0 (IBM Corp., 2012) statistics program. The following problem sentences related to the study were questioned by Regression and Correlation analysis. An attempt was taken to find a relationship between the number of coaches and athletes and the budget contribution provided to federations with sportive success?

\section{Study to find the answers:}

1. Is there a relationship between the budget contribution provided to sports federations independent of SHGM and sportive success?

2. Is there a relationship between the number of licensed athletes and sportive success? 
Table-1: Medals and Points in World and European Championships between 2007 and 2018

\begin{tabular}{|c|c|c|c|c|c|c|c|c|c|c|c|c|c|}
\hline \multirow[t]{2}{*}{ YEARS } & \multicolumn{2}{|c|}{$\begin{array}{l}\text { World Champ. } \\
\text { Gold medal }\end{array}$} & \multicolumn{2}{|c|}{$\begin{array}{l}\text { World Champ. } \\
\text { Silver medal }\end{array}$} & \multicolumn{2}{|c|}{$\begin{array}{l}\text { World Champ. } \\
\text { Bronze Medal }\end{array}$} & \multicolumn{2}{|c|}{$\begin{array}{l}\text { European Champ } \\
\text { Gold Medal }\end{array}$} & \multicolumn{2}{|c|}{$\begin{array}{l}\text { European Champ } \\
\text { Silver Medal }\end{array}$} & \multicolumn{2}{|c|}{$\begin{array}{l}\text { European Champ } \\
\text { Bronze Medal }\end{array}$} & \multirow{2}{*}{$\begin{array}{l}\text { World \& European } \\
\text { Champion. Average } \\
\text { Score }\end{array}$} \\
\hline & SayiSi & Puani $_{i}$ & Sayisi & Puani & Sayisi & Puani & Sayisi & Puani & Sayisi & Puani & SayiSi & Puani & \\
\hline 2007 & 34 & 204 & 26 & 104 & 44 & 88 & 49 & 245 & 48 & 144 & 80 & 80 & 144,17 \\
\hline 2008 & 40 & 240 & 39 & 156 & 82 & 164 & 72 & 360 & 68 & 204 & 117 & 117 & 206,83 \\
\hline 2009 & 63 & 378 & 51 & 204 & 100 & 200 & 109 & 545 & 110 & 330 & 132 & 132 & 298,17 \\
\hline 2010 & 44 & 264 & 69 & 276 & 112 & 224 & 100 & 500 & 122 & 366 & 150 & 150 & 296,67 \\
\hline 2011 & 44 & 264 & 55 & 220 & 117 & 234 & 102 & 510 & 114 & 342 & 189 & 189 & 293,17 \\
\hline 2012 & 62 & 372 & 82 & 328 & 124 & 248 & 105 & 525 & 153 & 459 & 171 & 171 & 350,50 \\
\hline 2013 & 69 & 414 & 102 & 408 & 115 & 230 & 140 & 700 & 141 & 423 & 190 & 190 & 394,17 \\
\hline 2014 & 73 & 438 & 96 & 384 & 138 & 276 & 111 & 555 & 146 & 438 & 194 & 194 & 380,83 \\
\hline 2015 & 51 & 306 & 63 & 252 & 105 & 210 & 194 & 970 & 195 & 585 & 234 & 234 & 426,17 \\
\hline 2016 & 106 & 636 & 117 & 468 & 172 & 344 & 185 & 925 & 194 & 582 & 255 & 255 & 535,00 \\
\hline 2017 & 93 & 558 & 102 & 408 & 174 & 348 & 239 & 1195 & 261 & 783 & 239 & 239 & 588,50 \\
\hline 2018 & 94 & 564 & 119 & 476 & 171 & 342 & 204 & 1020 & 214 & 642 & 317 & 317 & 560,17 \\
\hline
\end{tabular}

3. Is there a relationship between the number of active athletes and athletic success?

4. Is there a relationship between the number of coaches and sportive success?

5. Is there a relationship between the budget contribution provided to sports federations independent of SHGM and the number of licensed athletes?

6. Is there a relationship between the budget contribution provided to sports federations independent of SHGM and the number of active athletes?

7. Is there a relationship between the budget contribution provided to federations independent of SHGM and the number of coaches?

8. Does the budget contribution from SHGM affect sporting success?

9. Does the number of licensed athletes affect sporting success?

10. Does the number of active athletes affect sports success?

11. Does the number of coaches affect sporting success?

Results:

The period subjected to normality test is a 12-year period covering the years 2007-18. For this reason, Shapiro-Wilk test was applied and given in Table-3. The normality test shows that the data are normally distributed ( $\mathrm{p}>0.05)$.

Table 3. Shapiro - Wilk Normality Test Results

\begin{tabular}{llccc}
\hline Year & Parameter & Wilk & df & sig \\
\hline 2007-2018 & Aids from Shgm to Federations & .889 & 12 & .114 \\
$2007-2018$ & Number of Licensed Athletes & .933 & 12 & .414 \\
2007-2018 & Number of Active Athletes & .924 & 12 & .321 \\
2007-2018 & Number of Coaches & .947 & 12 & .600 \\
$2007-2018$ & World and European & .958 & 12 & .756 \\
& Championship Average Score & & & \\
\hline
\end{tabular}

The results of the analysis revealing the relationship between the scores obtained from the medals received in the World and European Championships, the number of coaches, the number of licensed and active athletes and the budget contribution made by SHGM to the federations; The results of the analysis on the effect of the budget allocated from the SHGM to federations, the number of coaches, the number of active athletes and the number of licensed athletes on sports success; The results of the analysis on the effect of the budget allocated from the SHGM to the federations on the number of licensed and active athletes and the number of coaches are included (see Table-4; Table-5; Table-6).

Table-4: Correlation Between 2007-18 Period World and European Championship Average Scores. Number of Coaches. Number of Active Athletes. Number of Licensed Athletes and Budget allocated from SHGM to Federations

Aid to Federations from 2007-2018 Shgm

$\begin{array}{llllll}\text { Pearson Corr. } & 1 & -.103 & -.248 & -.091 & -.009 \\ \text { Sig. (2-tailed) } & & .751 & .437 & .777 & .977 \\ \text { N } & 12 & 12 & 12 & 12 & 12\end{array}$

Number of Licensed Athletes between 2007-2018

$\begin{array}{llllll}\text { Pearson Corr. } & -.103 & 1 & .926^{* *} & .991^{* *} & .95^{* *} \\ \text { Sig. (2-tailed) } & .751 & & .000 & .000 & .000 \\ \mathrm{~N} & 12 & 12 & 12 & 12 & 12\end{array}$

Numbers of Active Athletes 2007-2018

Pearson Corr. $\quad-.248 \quad .926^{* *} \quad 1 \quad .913^{* *} \quad .911^{* *}$ $\begin{array}{lllll}\text { Sig. (2-tailed) } & .437 & .000 & .000 & .000\end{array}$ $\begin{array}{llllll}\mathrm{N} & 12 & 12 & 12 & 12 & 12\end{array}$ 2007-2018 Coaches $\begin{array}{llllll}\text { Pearson Corr. } & -.091 & .991^{* *} & .913^{* *} & 1 & .968^{* *}\end{array}$ $\begin{array}{lllll}\text { Sig. (2-tailed) } & .777 & .000 & .000 & .000\end{array}$ $\begin{array}{llllll}\mathrm{N} & 12 & 12 & 12 & 12 & 12\end{array}$

2007-2018 World and European Average Points Pearson Corr. $\quad-.009 \quad .958^{* *} \quad .911^{* *} \quad .968^{* *} \quad 1$ $\begin{array}{lllll}\text { Sig. (2-tailed) } & .977 & .000 & .000 \quad & .000\end{array}$ $\begin{array}{llllll}\mathrm{N} & 12 & 12 & 12 & 12 & 12\end{array}$

As a result of the correlation analysis between the budget allocated from SHGM for the federations and the number of licensed athletes, the number of active athletes, the number of coaches and the sportive success; No statistically significant relationship was detected ( $p>0.05)$, it was concluded that there was a significant relationship between the number of athletic achievements and the number of licensed athletes, the number of active athletes and the number of coaches $(\mathrm{p}<0.05)$.

As a result of the regression analysis; It is concluded that there is no statistically significant relationship ( $\mathrm{p}>0.05$ ) between the budget allocated from SHGM and the World 
and European Point Averages ( $p>0.05$ ), which reveals sportive success. In terms of other independent variables such as the number of coaches, active and licensed athletes; there is a significant relationship between these variables and sportive success $(\mathrm{p}<0.05)$. It was concluded that the number of coaches and the number of active and licensed athletes positively affected sports success (see Table-5).

Table 5. Simple Linear Regression Analysis Results Regarding the Effect of the Budget, Number of Trainers, Number of Active Athletes and Number of Licensed Athletes allocated from the SHGM for the 2007 - 2018 Period on the Average Score of the World and European Championships

Variables

$\mathrm{R} \quad \mathrm{R}^{2} \quad \mathrm{~F} \quad$ ? $\quad \mathrm{t} \quad \mathrm{p}$

Independent Variable: Budget allo. from SHGM to Federations Dependent Variable: World and European Average Points

$$
\begin{array}{llllll}
0009 & 0000 & 0001 & -009 & -030 & 097
\end{array}
$$

Independent Variable: Number of Coaches

Dependent Variable: World and European Average Points
0.968
0.937
147.582
0.968
$12.148 \quad 0.000$

Independent Variable: Number of Active Athletes

Dependent Variable: World and European Average Points
0.911
0.82
48.615
0.911
6.972
0.000

Independent Variable: Number of Licensed Athletes

Dependent Variable: World and European Average Points

$$
\begin{array}{llllll}
0.958 & 0.917 & 110.834 & 0.958 & 10.528 & 0.000
\end{array}
$$

As a result of the regression analysis; It is concluded that there is no statistically significant relationship ( $p>0.05$ ) between the budget allocated from SHGM and the World and European Point Averages ( $p>0.05$ ), which reveals sportive success. In terms of other independent variables such as the number of coaches, active and licensed athletes; there is a significant relationship between these variables and sportive success $(\mathrm{p}<0.05)$; It was concluded that the number of coaches and the number of active and licensed athletes positively affected sports success (see Table 5 ).

Table-6: Simple Linear Regression Analysis Results Regarding the Effect of Budget allocated from SHGM to Federations in 2007-2018 Period and Number of Active and Licensed Athletes and Coaches

Variables

$\begin{array}{llllll}\mathrm{R} & \mathrm{R}^{2} & \mathrm{~F} & ? & \mathrm{t} & \mathrm{p}\end{array}$

Independent Variable: Budget allocated from SHGM to Federation Dependent Variable: Number of Active Athletes

$$
\begin{array}{llllll}
0.248 & 0.062 & 0.657 & -.248 & -.810 & 0.437
\end{array}
$$

Independent Variable: Budget allocated from SHGM to Federation

Dependent Variable: Number of Licensed Athletes

$$
\begin{array}{llllll}
0.103 & 0.011 & 0.106 & -.103 & -.326 & 0.751
\end{array}
$$

Independent Variable: Budget allocated from SHGM to Federation

Dependent Variable: Number of Coaches

$$
\begin{array}{llllll}
0.091 & 0.008 & 0.084 & -.091 & -.290 & 0.777
\end{array}
$$

As a result of the regression analysis between the budget allocated from the SHGM to federations and the number of coaches, number of active athletes and number of licensed athletes; No statistically significant relationship was detected $(\mathrm{p}>0.05)$.

\section{Discussion:}

The increase in the sports budget, the number of athletes, thats the increase in the number of athletes would increase the number of medals, and thus there is a statistical relationship between the sports budget and the number of athletes, and when the budget increases, the number of athletes increases, but the increase in the number of athletes does not affect the number of medals. In addition, in the study of Elmas (2016), it was revealed that there was no relationship between the budget and the number of medals.

No statistically significant relationship was found between the budget contribution made to the federations by the General Directorate of Sports Services and the number of coaches and active \& licensed athletes. In addition, it was concluded that the number of coaches and the number of active and licensed athletes affect the sportive success. In this study, there is a statistical relationship between the sports budget and the number of athletes; Stating that the increase in the number of athletes does not affect the number of medals, Elmas (2016) didn't confirm his work in both aspects. However, this study supports the study of Elmas (2016), which concludes that there is no statistical relationship between the budget and the number of medals.

Güngör (2014) revealed a parallel between sportive success and income from professional football activities; Barajas et al., (2005) reveal a nonlinear relationship between the budget of Spanish football clubs and sports performance which do not support our work in terms of the relationship between budget and sports success. As a result, the findings we obtained from this study seem to be partially supported by a small number of similar studies. This reveals the need for comprehensive studies on the subject in the future.

\section{Limitationsand Recommendations:}

This study covers the period of 2007-2018, when federations became autonomous. It is recommended that future studies examine the post-autonomy and pre-autonomy period comparatively.

In this study, sportive success was evaluated according to the total number of medals obtained in the World and European Championships. It is thought that future federation-based studies, in which each federation is handled separately, will contribute to the literature in terms of federations.

This study is independent from the inflation effect. As it is known, inflation; It is def ined as the continuous decrease in the purchasing power of money, which is the unit of value measurement for goods or services, with the price level constantly increasing (Çatalok, 2019; Yaldiz, 2018). Therefore, inflation; it affects income distribution, capital accumulation, investments, taxes, borrowing, costs, 
financial performance and ultimately economic development. In this respect, future studies that take into account the effect of inflation will increase the contribution to the literature.

In this study, although documents such as the balance sheet, income-expenditure table, and audit committee report published in the Federation Announcements of the General Directorate of Sports Services for years have been partially accessible, it has not been possible to reach all of them. Due to the deficiencies in these documents, our study was limited with the relationship between the budget contribution provided by the General Directorate of Sports Services to the federations in terms of economic indicators and sportive success. It is important in terms of transparency and trust that the federations present their documents such as their balance sheet, income-expense table and the report of the supervisory board to open access foryears. In future studies, it is recommended to examine in detail the relationship between federation revenues and the main elements that make up these revenues and sportive success.

\section{References:}

Altun, M. \& Koçak, S. (2015): Turkey's evaluation in terms of sporting achievement: Baku European Games instance. Hacettepe J. Sport Sci., 26(3):114-128.

Aykin, A.G. \& Bilir, F.P. (2013): Government programs and sports policies. _._Cukurova Univers. Ins. Soc. Sci., 22(2):239254 .

Barajas, A., Fernandez, C., Crolley, L. \& Crolley, J. (2005): Does sports performance influence revenues and economic results in Spanish football? Munich Per. Repec Arch., Paper No:3234

Bernard, A.B. \& Busse, M.R. (2004): Who wins the olympic games: economic resources and medal totals. Revi. Eco. Stat., 86(1):413-417.

Basar, M. (2001): ). Effects of false perception of success in families on students. Afyon Kocatepe Univers. J. Soc. Sci., 2(2):115-124.

Çatalok, C. (2019): The impact on tax revenues inflation in Turkey (1990-2018) (M.Sc.). Aydın Adnan Menderes University Institute of Social Sciences, Aydın, Turkey.

Elmas, Y. (2016): Number of athletes, budget and success relationship. USAD, 6(2):37-46.

Erkan, A. (2014): Examination and evaluation of the effects of budget policies on the services provided in the field of sports. HAK-ISS Int. J. Labor Soc., 3(5):110-131.

Ersöz, G. \& Alagöz, B. (2019): The distribution of the number of athletes by sport and gender in Turkey between the years 2007-2017. L. Sports Sci. Turkey TUSBID, 3(2):42-65.
Göllü, E. (2012): Impact of the financial performances of incorporations of football clubs in the domestic league on their sportive performances: A study covering four major football clubs in Turkey. Pamukkale J. Sport Sci., 3(1):20-29.

Güngör, A. (2014): Analysis of the relationship between financial performance and practice in Turkey with sporting success in the football industry Istanbul Üniversitesi Sosyal Bilimler Dergisi, 1(1):16-36.

Jayantha, K. \& Ubayachandra, E.G. (2015): Going for gold medals: factors affecting Olympic performance. Int. J. Sci. Res. Pub. (IJSRP), $5(6): 1-7$.

Pereira, T.M.V. (2018): The relation of financial performance and the sports performance in football clubs (Master's Dissertation). Universidade Do Porto Faculdade De Economia, Porto.

Rohde, M.\& Breuer, C. (2016): Europe's elite football: financial growth, sporting success, transfer investment, and private majority investors. Int. J. Finan. Stud., 4(12):1-20.

Seiler, S. (2013): Evaluating the (your country here) Olympic medal count. Int. J. Sports Physiol. Perform., 8(2):203-210.

Saatçioglu, C. (2013): Spor Ekonomisi Teori, Politika ve Uygulama. Pub. by: Gazi Kitabevi, Ankara.

Saatçioğlu, C. (2013). Sport Economics Theory, Policy and Practice. Pub. by: Gazi Bookstore, Ankara:, Turkey.

\section{Further Readings:}

Amounts Paid from Independent Sports Federations from SGM Budget (2004-2019). From: (ulker.ercin@sgm.gov.tr) Access: 18.02.2020

Independent Sports Federations Accounting and Budget Implementation Directive, www.shgm.gsb.gov.tr/Sayfalar/254/241/mevzuatyonergeler.aspx, Access: 04.05.2020

Application-Oriented Accounting and Registration Procedures and Principles of the Independent Sports Federations Accounting and Budget Implementation Directive (Directive Annex - A), www.shgm.gsb.gov.tr/Sayfalar/254/241/mevzuat-yonergeler.aspx, Access : 04.05.2020

Number of Coaches ( $2007-2018)$. Website : (www.sgm.gsb.gov.tr/Sayfalar/175/105/Isistikler) Access: 21.12.2019

IBM Corp. IBM SPSS Statistics for Windows, Version 21.o, Armonk, NY: IBM Corp., 2012.

Genel Madalya Dagilimi ve Basarili Sporcularimiz (2000 - 2018). Website: (www.sgm.gsb.gov.tr/Sayfalar/175/105/Istatistikler) Erisim: 20.12.2019

Kuruluslar Itibariyla Bütçe Ödenekleri ve Harcamalari (1924-2019): Website: (www.hmb.gov.tr/bumko-butce-buyuklukleri-ve-butcegerceklesmeleri) Erisim: 17.02.2020

Istanbul Serbest Muhasebeci Mali Müsavirler Odasi. (2012). “Türkiye'nin spor bütçesi: Madalyanin maliyeti yüksek" raporu. Rapor No: 2012/12. Istanbul: ISMMMO.

Bütçe, www.sozluk.gov.tr, Erisim: 05.05.202

Budget Allocations and Expenditures by Organizations(1924 - 2019). Website: (https://www.hmb.gov.tr/bumko-butce-buyuklukleri-vebutce-gerceklesmeleri) Access: 17.02.2020

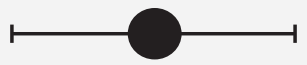

